\title{
133
}

UDC: $339.13 .027: 334.012 .64 / .65(680)$

DOI: 10.5379/urbani-izziv-en-2013-24-02-005

\section{Improving market access opportunities for urban small, medium and micro-enterprises in South Africa}

Since the democratic transition of 1994, the promotion of the small, medium and micro-enterprise (SMME) economy has been a core focus of South African government policy. With high levels of unemployment and poverty in urban areas, the impact of this policy intervention is most critical for city development. Given South Africa's chequered history, the national government's focus is on transforming the prospects for enterprises owned by black South Africans, who were disadvantaged under apartheid. This article examines the range of contemporary policy initiatives to address business constraints on market access and catalyse new market opportunities for black-owned enterprises in urban South Africa. The article concentrates on two themes: 1) building links into private sector supply chains, especially through supplier diversity, and 2) building links into public sector markets through public procurement. It is shown that current policy directions recognise that the national government has a limited capacity to implement SMME improvement and build competitive black-owned SMMEs by itself, which has prompted support for private sector initiatives. In addition, the government is struggling to practice what it preaches and use its own procurement capacity to assist black-owned SMMEs.

Key words: market access, links, urban small, medium and micro-enterprises, private sector procurement, public procurement 


\section{Introduction}

In seeking to achieve the targets of the Millennium Development Goals by 2015, one of the most critical challenges for urban Africa is generating new "productive employment opportunities and livelihoods for the 7-10 million young people who are entering the labour force each year, a disproportionate amount of whom will live in cities" (Thornton \& Rogerson, 2013: 1). Given the significance of this challenge, it is remarkable that "research on the economy of African cities has been seriously neglected for at least the last decade" (Turok, 2010: 18). Among others, Ivan Turok (2012) maintains that the imperative is to identify a set of policies to strengthen African urban economies and above all make them more inclusive. With only limited prospects for job creation in the large private sector, government or parastatal enterprises, the focus of policy attention has increasingly shifted in many countries to the prospects of employment creation by small, medium and micro-enterprises (SMMEs), which constitute the majority of enterprises across sub-Saharan Africa (Rogerson, 1997; Kessides, 2007). The question arises whether the mass of existing SMMEs can be developed and transformed to become more productive and growth-oriented businesses that generate improved livelihoods, decent work opportunities and tax revenues to finance improved public services and infrastructure (Turok, 2012). "Informality", informal economic spaces and informal work dominate the African urban landscape with limited rewards for participants, often as a result of saturated markets and the absence of capital, skills and technology (Grant, 2010; Meagher, 2010; Turok, 2010). As has been observed by several analysts, growth in the African informal economy is mainly of an extensive or involutionary character, with the proliferation of more of the same forms of informal enterprise rather than a transitioning towards more established and dynamic small-scale enterprises (e.g. Rogerson, 1997; Bryceson \& Potts, 2006; Turok, 2012). One critical imperative across urban Africa is to trigger the environment for the emergence of a dynamic economy of small-scale enterprise development. In Africa this challenge impacts local economic development and the building of robust economies, which is felt most acutely in cities (Kessides, 2007; Rogerson, 2010; Rogerson \& Rogerson, 2010; Thornton \& Rogerson, 2013). As pointed out by Turok and Susan Parnell (2009), addressing many of the critical challenges of rapid urban development in urban Africa is beyond the current capacity of local governments to manage or respond.

Several writers point to the potential imperative for concerted state support for leveraging improvement of the small-scale enterprise economy for dynamic expansion (Rogerson, 1997; Bryceson \& Potts, 2006; Turok, 2010). In particular, the capac- ity of the national state to support improvement of small-scale enterprises is scrutinised. One African country that has had an extended period of support initiatives to support and improve the SMME economy is South Africa. Since the democratic transition of 1994, the promotion of entrepreneurship and improving the SMME economy have been a central focus of South African government policy (Rogerson, 2004a, 2004b; Urban, 2006; Timm, 2011). Two decades after democratic change, joblessness and insufficient livelihood opportunities are enduring problems that blight the South African urban environment (Boraine et al. 2006; Turok \& Parnell, 2009; Freund, 2010; Grant, 2010; Schenck \& Blaauw, 2011; Ligthelm, 2012). With continued high levels of unemployment and poverty across the country, especially in the largest cities, SMME development continues as a policy priority almost twenty years after the end of apartheid. The recent National Development Plan, which offers a vision for 2030, reasserts a commitment to the importance of improving the SMME economy (The Presidency, 2011). Likewise, in the New Growth Path, the major guiding economic strategy, and in policy documents of the Department of Trade and Industry (DTI), the lead government ministry responsible for the economy and tasked with enterprise development, continued emphasis is placed on support for the SMME economy (Department of Economic Development, 2010; DTI, 2011). Given the country's history, the policy focus of national government is particularly on transforming the prospects for those enterprises established and owned by black South Africans that were disadvantaged under apartheid. The difficulties and constraints facing this large community of SMMEs (the majority of them urban informal sector survivalist enterprises) are documented and analysed elsewhere (Rogerson, 2004b, 2004c, 2006, 2008; Timm, 2011; Ligthelm, 2012). Above all, the core business problems of potential growth-oriented small-scale enterprises, particularly in cities, relate to a complex suite of issues surrounding lack of access to markets, lack of access to finance and shortcomings in the support environment.

This article examines a range of contemporary policy initiatives that are targeted by the national government and the private sector to address issues of market access and thus forge new market opportunities for black-owned enterprises in South Africa. Although rural SMME development is a critical issue in South Africa, the core impacts of national government SMME development interventions concentrate on enhancing business development in major cities and secondary centres. As pointed out, this situation offers a critical nexus between national government policy on the one hand and, on the other hand, local imperatives for encouraging SMME development as part of local economic development programming (see Nel \& Rogerson, 2005; Rogerson, 2011; Rogerson \& Rogerson, 2012). 
The analysis contributes towards understanding the essential policy dynamics from the national level that impact the unfolding landscape of SMME development in urban South Africa. More specifically, the focus is on growth-oriented small enterprises as opposed to issues pertaining to the informal economy of survivalist enterprise, which merit separate discussion and analysis.

Methodologically, use is made of mixed methods. First, and most importantly, a series of interviews were undertaken with influential government, private sector and SMME stakeholders. Interviews related to this research included those with key stakeholders and policy makers in 2009 and 2010 at the national Department of Trade and Industry (DTI), the National Treasury, the Small Enterprise Development Agency (SEDA), the private sector body, the private sector National Business Initiative (NBI) and the National Small Business Advisory Council. Second, information from the interviews was triangulated with documentary material, including access to internal organisational reports about the progress of SMME policy implementation in South Africa. Third, the findings of this analysis were addressed in workshops with all key stakeholders in the SMME economy: the national government, the Small Business Development Agency, the private sector and representatives of the National Small Business Advisory Council.

The article focuses on two themes: 1) building links to private sector supply chains, especially through supplier diversity, and 2) building links to public sector markets through public procurement. The significance of these two themes is underscored by the National Development Plan, which asserts that "public and private procurement will be an essential stimulator of demand for small and expanding firms" (The Presidency, 2011: 119). The discussion is organised into three further sections of material. These deal with the changing directions of national government policy in South Africa towards the challenges of SMME development and are followed by critical discussions of emerging policy initiatives for building links in private sector procurement and opportunities for SMME development linked to public sector procurement. Overall, the analysis is a contribution to understanding the changing fortunes of a critical segment of the SMME economy in contemporary South Africa, which has major implications for urban employment and livelihoods. In addition, it represents a modest contribution towards expanding the limited corpus of scholarship on dynamising small-scale enterprises in urban Africa. An examination of the South African policy experience, one of the most mature in Africa, can potentially offer learning or lessons in relation to policy towards SMME development in other parts of Africa.

\section{South Africa's SMME economy: Challenges and policy responses}

Alongside issues of enhanced access to finance and an improved regulatory and support environment, the core problem of South Africa's city-based SMMEs, especially of emerging black-owned SMMEs, relates to their weak access to market opportunities (Timm, 2011). Inadequate access to market opportunities is revealed as a major cause of enterprise failure and the high rate of "churning" of the SMME economy. It can be argued that there are three key dimensions of market access of different SMMEs that need to be addressed in South Africa.

The first issue is sectoral disadvantage, which arises from the fact that the majority of small enterprises in cities are over-concentrated in activities and specific segments of the economy with low growth potential. In certain activities such as retailing, saturation exists such that only limited returns are possible and most businesses operate only at meagre survival levels. A key policy issue that must be addressed in enhancing market access is achieving business diversification or "break out", shifting the balance of small enterprises away from the massive concentration of entrepreneurs in activities that have low growth potential into activities with higher potential. A second issue is to address problems of market access that arise from the location of businesses. Issues of market limitations because of geographical access are experienced by many small enterprises providing goods and services. Disadvantage is experienced as a result of the market limitations imposed by a business location that constrains access. This spatial disadvantage is reflected at many scales: from the national level by enterprises in remote or rural areas to the urban scale, where many disadvantaged entrepreneurs are compelled to operate their businesses from peripheral locations, thus reducing their access to market opportunities. The third and most important market access issue that must be addressed relates to building up the competitiveness of small enterprise suppliers of goods and services (relative to existing often white-owned enterprises) to enter and participate in private sector and public sector supply chains. Indeed, in the context of globalisation, the issue is building competitiveness for certain categories of (almost exclusively urban-based) SMMEs to participate not only in domestic supply chains but also potentially as participants in global supply chains.

In reviewing nearly twenty years of government support and intervention for the SMME economy in South Africa, it is evident that the challenge of overcoming market access has been one consistent thread in policy support since 1994. In 1995 an entirely new set of policy initiatives and institutions 
was established to support the local SMME economy based on international "best practice" (Rogerson, 2004b). Among a suite of initiatives were the establishment of separate institutions for dealing with finances and non-financial arrangements, and encouraging subcontracting/link arrangements. The major achievements of the first decade of SMME support relate to establishing a new architecture for supporting the SMME economy, which was largely neglected throughout the apartheid era. Several disappointments surrounded the first decade, however; most notably that few of the targeted SMMEs were growing businesses and that, in terms of the limited funding that was allocated to programme support, little reached the struggling communities of black-owned enterprises. Among the reasons offered for the poor performance were funding constraints, weak policy coordination and implementation, and the fact that the existing policy benefits were captured by medium-sized enterprises, often white-owned enterprises rather than the ostensible core target groups of emerging black-owned SMMEs, which continued to be economically marginalised (Rogerson, 2004b).

One outcome of these disappointments was a reassessment of the existing policy framework and the workings of existing institutions. A new policy framework was launched after 2006: the Integrated Small Business Development Strategy (DTI, 2006). This policy framework was rooted in building three pillars of support for the SMME economy. These were to expand access of SMMEs to credit/finance, extend the access of SMMEs to market opportunities and engage government with regulatory reform issues (DTI, 2006). Alongside fresh policy changes, a new institutional support framework was forged with the launch of the national Small Enterprise Development Agency with a mission to ensure better coordination and integration of policy initiatives. This new support structure was reviewed for progress in the five-year period from 2006 to 2011 (Osiba Research, 2011). The key conclusions of this review once again re-assert the so far minimal impact of government programmes to support improving the majority of black-owned SMMEs and integrating them into the mainstream economy. Arguably, this assessment relates to a period in government policy that has been more proactive and targeted towards the emerging black-owned SMME economy than the first decade of post-apartheid SMME policy interventions.

Importantly, the core analysis is that the continued disappointments of South African SMME are not so much about misguided policies, but the inability of government to implement its own support programmes (Osiba Research, 2011). This theme can be investigated further by examining issues of market access for SMMEs. Implementation of market access improvement has shifted to focus critically on two strategic initiatives: greater engagement with the private sector for ex- tending its procurement to SMMEs and expanded application of public sector markets and public sector procurement as a lever for market access.

\section{Private sector procurement initiatives}

An extensive international literature supports the view that building economic links is one of the fastest and most effective ways of improving SMMEs, not least of all through facilitating their access to markets and finance (United Nations Conference on Trade and Development, 2006). The activities of international agencies, donors and national governments have encouraged an array of different initiatives for fostering business links. It is maintained that there are both competitiveness and corporate social responsibility arguments in favour of expanding business links with SMMEs (Jenkins, 2007; Jenkins \& Ishikawa, 2009). The weight of international evidence is moving towards asserting the "business case" for large firms to establish and support link programmes with SMMEs as suppliers of goods and services. It is acknowledged that the phenomenon of "supplier diversity" is increasingly important in business strategy (Rogerson, 2012). Correspondingly, a number of SMME writings centre on the significance of encouraging "supplier diversity" and interventions specifically designed to generate diversity in SMME supplier development programmes. In many countries, the issue of supporting supplier diversity has moved from the margins of discussions concerning SMME development to become a mainstream policy matter (Ram \& Smallbone, 2003a, 2003b; Sonfield, 2010). In particular, questions concerning supplier diversity have been prominent in the U.S., the UK and more recently Australia. In all three cases, the focus on supplier diversity relates to the promotion of "minority businesses" in the U.S., "ethnic minority businesses" in the UK and "indigenous opportunities" in Australia (Rogerson, 2012). Henry Adobor and Ronald McMullen (2007: 219) confirm that supplier diversity has become increasingly prominent because large enterprises "have recognized economic benefits of broadening their supplier base to include minorities".

As highlighted by David Toomey (1998), the history of South African initiatives seeking to link SMMEs (including black suppliers) into the supply chains of large private sector enterprises goes back to the apartheid period. During the 1980s and early 1990s, a number of high-profile corporate initiatives were launched by mining firms and certain other leading companies designed to improve the capacity of black-owned enterprises and to potentially incorporate the capacitated enterprises into corporate supply chains (NBI, 2006a). Several of the earliest examples of these programmes are considered to have been 
driven by non-economic motivations associated with earning a local license to operate in certain communities, but "in the long run they are commercially driven" (NBI, 2006b: 6). Prior to 1994, however, these private sector initiatives for greater outsource opportunities with mining companies were exceptional cases. Moreover, the initiatives were localised with only a limited scale of impact. Accordingly, Toomey (1998: 136) states that "prior to 1994 the private sector was scarcely involved in assisting the development of black emergent entrepreneurs, although private industry was, arguably, the most experienced and in the best position to promote black entrepreneurs". Furthermore it was made clear that "most South African experience with inter-firm linkage consisted predominantly of efforts that are best described as corporate social responsibility, actions of social goodwill that were generated by the non-core activity of the enterprise" (Toomey, 1998: 148). After democratic transition, the imperatives for revitalising the economy, deepening the structures of production and ensuring greater economic participation by all groups in society meant that corporate social goodwill was simply insufficient to meet new expectations, particularly in urban areas.

Since the early years of the new democracy, more energetic efforts have been made to open new market opportunities for SMMEs through leveraging market links between SMMEs and large corporations. The outcome of these initiatives in the first decade of democracy was, however, limited (Rogerson, 2004a). Starting in 2005, the national government adopted a more aggressive approach to leveraging the opportunities around private sector procurement. Of particular significance was the gazetting of the Broad-Based Black Economic Empowerment Bill (B-BBEE) in 2004, the main legal instrument covering a range of diversity-related issues, including implementation of preferential procurement. For many observers, B-BBEE is regarded "as one of South Africa's most critical business imperatives, now and in the future" (Juggernauth et al., 2011). It is argued that the B-BBEE act "had the effect of turning the spotlight onto corporate South Africa's contribution to redressing the economic and social imbalances in the country" (Skae, 2006: 4). Essentially, the purpose of this legislation was that "through a system of compliance, the intention is to ensure that any entities who wish to meet qualifying criteria for licences or concessions, supply goods or services to any organ of state or public entity, acquire state-owned enterprises and enter public-private partnerships would have to demonstrate their commitment to Black Economic Empowerment" (Skae, 2006: 4). The policy environment for expanded public and private sector procurement was further strengthened by the issuance of the B-BBEE Codes of Good Practice in 2007 and of the associated balanced scorecard (Herrington \& Overmeyer, 2006). The core purpose of the Codes of Good Practice was "to assist and advise both the public and private sectors in their implementation of the objectives of the B-BBEE act" offering a set of principles and guidelines that might facilitate the implementation of B-BBEE in a meaningful and sustainable manner (Botha \& Van Vuuren, 2006: 8). Simply put, the higher an organisation's B-BBEE score, the easier it would be to transact business directly or indirectly with local, provincial or national government and state-owned enterprises in South Africa. The adoption of preferential procurement was one key element of the generic scorecard introduced by the Department of Trade and Industry to measure the progress of business in achieving B-BBEE. The codes articulate the goal of "preferential procurement which encourages established businesses to procure from black-owned, black-controlled businesses" (Herrington \& Overmeyer, 2006: 8). Essentially, this encourages participation through market access and integrates black business into the mainstream of the economy.

Under the scorecard, it was suggested that a minimum of twenty percent of procurement spent by corporations should be allocated to Black Economic Empowerment (BEE)-qualifying enterprises. A number of investigations, however, pointed out resistance and a lack of commitment to support BEE suppliers by many large organisations, resulting in an inherently weak approach to supporting the making of competitive SMMEs (Herrington \& Overmeyer, 2006; Rogerson, 2012). Several key factors underpin the reluctance of large firms to link with emerging black-owned businesses; namely, the absence of capacity of SMMEs to respond to the needs and requirements of large enterprises, the absence of "partnerships of equals" and the tendency of many small enterprises to become dependent on particular linkage relationships with large firms, and the limited existence of conducive business practices by large firms that might support links (NBI, 2006a). Among the most significant issues are limitations in access to information about business opportunities, the short-term nature of contracts, payment cycles that produce cash flow difficulties for SMMEs, limited use of set-asides, and break-up of contracts and performance guarantees. Other obstacles to developing links relate to the limitations of committed leadership in large firms (especially in procurement staff for SMME links) and the need for large firms to shift away from the viewpoint of business links as a form of corporate social investment (NBI, 2006a).

Notwithstanding the legislative driver for South African large firms to engage SMMEs in their supply chains by the mid-2000s, the case for developing private sector business links rested on a growing weight of local and international evidence that supported the business case for developing links and supplier diversity. Traditionally, in South Africa large corporations preferred to deal with large (mainly white) suppliers (Toomey, 1998; Herrington \& Overmeyer, 2006). In common with the 
experience of the U.S. and UK, large firms in South Africa increasingly acknowledged the business case for catalyzing private sector-led initiatives that would be targeted to broaden value chains and incorporate black small businesses. Arguably, the role of the National Business Initiative has been influential in popularising the "business case for commercial linkages in South Africa between large and small enterprises" (NBI, 2006a: 4). The organisation asserts that "interfirm linkages can substantially improve the procurement, production, marketing and distribution value chain within a specific industry" (NBI, 2006a: 27). Emphasis is placed on opportunities for large firms to enhance their market penetration and to the asset offered to large firms by tapping the "agility of small enterprises" with respect to their more cost-effective structures for handling small orders (NBI, 2006b: 14).

Overall, the national picture of business link development in South Africa has largely focused on large firms purchasing a range of goods and services from small business suppliers, thus widening their distribution or sub-contracting networks (Skae, 2006). Other potential areas of participation in corporate value chains such as design or product development have been minimal. The untapped potential is also highlighted for small enterprises to maximise the advantages of specialisation or geography in terms of functioning as a distribution channel for large enterprises (NBI, 2006a). Key issues identified to facilitate the growth of commercial links between large and small enterprises in South Africa mainly reflect international experience; namely, the need to build capacity among small enterprises, monitoring fronting, avoiding dependency relationships, improving small enterprises' access to information, using shorter payment cycles, breaking up contracts, improving access to finance by issuing performance guarantees, allowing price matching as part of simplified tender processes, securing high-level committed leadership and buy-ins for linkage schemes, and support for a wider enabling environment for SMME development through government support programmes assisting SMME entrepreneurs (Herrington \& Overmeyer, 2006; NBI, 2006b). The key findings include the fact that government SMME policies were ineffective in supporting the kinds of enterprises that might link with large firms and that the private sector in South Africa has so far only been involved in creating a support system for delivering services to SMMEs (NBI, 2006b).

The apparent shift in government policy emphasis from support of SMMEs per se to Black Economic Empowerment (BEE) resulted in many large private sector firms shifting their focus away from SMMEs to support for BEE. Under the existing legislation, a number of observers point out that corporate businesses prioritise the objectives of B-BBEE over enterprise development and significantly "few place an emphasis on local content and local supplier development" (Altman, 2010: 41). Indeed, large enterprises could often achieve BEE accreditation in the absence of any serious commitments to enterprise development. Many South African corporations set up programmes and structures aimed at meeting government targets for preferential procurement and enterprise development with varying degrees of success. Most importantly, it was revealed that in most cases these are standalone programmes that function at the periphery of the corporation's business strategy and mainstream operations, and that as such these programmes are often simply seen as a cost of doing business rather than as an investment in the corporation's future competitiveness or sustainability.

The policy debate in South Africa around business links has progressively reoriented to examine questions of "supplier diversity", although in this case the focus is not on "minority enterprises" but on enterprises that are owned by black South Africans, the majority population. Here the focus is on the role of large private sector organisations assisting in building the capacity and competitiveness of specifically historically disadvantaged SMMEs and explicitly linking them into market opportunities. A critical landmark was the establishment of the South African Supplier Diversity Council (SASDC) in 2010, which is a parallel organisation to the U.S. National Minority Supplier Diversity Council and part of a global network of supplier diversity councils (SASDC, 2011). The mission of SASDC is to be a leader in promoting sustainable supplier diversity added value through targeted procurement and black supplier development. The SASDC stresses the business case for integrating supplier diversity into the corporate supply chain strategy and is articulated in terms of six issues. These include improved supply chain competitiveness, product innovation through interaction with new supplier enterprises, enhanced corporate brand image with communities, shareholders and government, better market economic intelligence because of closer supplier relationships, increased market share and loyalty, and securing greater access to public sector (and private sector) business opportunities through BEE compliance (SASDC, 2011). At its core, SASDC is driving a process of corporate economic transformation in South Africa with its essential focus to enable its members to practice supplier diversity as a strategic objective through three major activities (Joseph, 2010).

The first activity is establishing and maintaining a database of certified black-owned suppliers for members to access. The SASDC process of certification is rigorous in terms of verifying ownership status and deterrence of "fronting", and in ensuring quality suppliers capable of supplying goods and 
services to members' required standards of (Ismail \& Haselau, 2010). The second activity is sharing best practice experience and knowledge about supplier diversity. The third activity is supporting members in growing procurement and development opportunities for black-owned supplier enterprises. Key interventions include matchmaking, promoting educational research directed at expanding black-owned enterprises, hosting business opportunity fairs and "meet the buyer" events to facilitate business relationships between SASDC members and certified black suppliers, and providing assistance to members in establishing, implementing or expanding their targeted procurement programmes (SASDC, 2011).

Beginning in 2010, supplier diversity initiatives were launched and expanded in South Africa by the private sector with no government support. A new chapter of opportunity opened in South Africa in the application of private sector procurement as a lever for building the capacity of black-owned SMMEs to enter corporate supply chains with the positive endorsement by national government of the activities of SASDC during 2011 and 2012. National government now endorses the role of the private sector in leading this important and growing initiative for building links with black enterprises through an extended programme of private sector procurement, which has the opportunity to synergise with existing government support initiatives.

\section{Public sector procurement}

It has been observed that public procurement, which is a major function of governments, is a neglected area of academic research (Thai, 2001; Mahmood, 2010). Public sector procurement has been applied as a lever for SMME development in many countries around the world, especially by using set-asides to promote market access for certain preferred groups of SMMEs. Recently, one observer opined that "South Africa could vamp up support to small businesses if it looked at setting aside certain types of procurement for SMEs, as a number of countries like South Korea, the US and Japan already do" (Timm, 2011: 43). In Canada, set-asides are applied in certain government contracts with mandatory provisions for "Aboriginal" suppliers (Orser, 2009: 23). Instead of relying on procurement goals or targets that relate to small business sourcing, often from disadvantaged groups, "set-asides reserve certain purchases for competition only among a certain group of disadvantaged owners of SMEs" (Orser, 2009: iii). Set-asides are flexible tools widely used in the U.S. to support small businesses as a whole and for supporting specific targeted kinds of small business, such as minority-businesses and women-owned businesses (Bates, 2001; House-Soremekun, 2007). Although their impacts are contested, several analysts praise these pro- grammes, emphasising that they were "necessary to level the playing field and create opportunities for minority business creation and growth" (Sonfield, 2010: 12). Arguably, one consequence of preferential procurement was that new markets were opened up for minority enterprises, which allowed them to diversify their activities away from the traditional focus on retail and personal services.

Phoebe Bolton (2006) makes it clear that prior to the democratic transition in 1994 the government procurement system in South Africa favoured large and established businesses and created an environment in which it was very difficult for small enterprises to enter the procurement system. In 1994, however, government procurement was granted constitutional status and acknowledged as a vehicle for addressing past discriminatory practices (Bolton, 2008). Public procurement has been applied since 1994 as a policy tool "to correct South Africa's history” (Bolton, 2006: 202). Of critical importance has been that, in procuring goods and services, organs of the South African government are required to take into account a number of factors when awarding state contracts. As Phoebe Bolton (2006: 202) stresses, the concept of "empowerment" "plays an important role in determining whether or not a contract is awarded to a particular contractor". Provision is made for implementing a policy of what is described as "affirmative" or "targeted" procurement, which is aimed "at providing employment and business opportunities for marginalized individuals and communities - referred to as 'target groups" (Bolton, 2008: 2). In addition to the policy focus on Black Economic Empowerment, growing interest has centred on using public procurement as a strategic tool to support the objectives of SMME development policies. In South Africa the cabinet approved the "Ten Products Initiative" in 2007, under which the government would only procure certain products from (black) SMMEs. The Government Preferential Procurement for Small Enterprise Products and Services isolated ten product and service categories to be supplied by SMMEs. The ten product categories identified as targets for SMMEs were advertising, media and communication; interior and exterior cleaning services and cleaning product supplies; clothing and textiles; computer equipment and consumable supplies; interior and exterior furniture and décor; events coordination and management; maintenance and repairs, construction, office space, furniture and vehicle body works; travel coordination and shuttle services; perishable food supplies (catering); and stationary supplies and printing (Kaiser Associates, 2010).

Implementing this initiative has been stalled such that, although the government is encouraging (and increasingly compelling) the private sector through B-BBEE codes to expand links with black-owned enterprises, it has not been 
practicing this in its own direct procurement. Notwithstanding a subsequent cabinet resolution on ten targeted goods and services that were designated for procurement by SMMEs in all public sector procurement activities, by 2012 this resolution had not been implemented. In terms of reasons for the lack of implementation, Stephen Timm (2011: 46) reported that National Treasury "probably shares the concern that many other governments around the world have with set-asides, namely that putting in place set-asides will result in inflating the costs of procurement". In interviews with officials from the National Treasury, however, it was made clear that their core objections with set-asides and the ten-product targeted procurement plan relate to the "unconstitutional" nature of set-asides. As is made clear by Nomonde Mesatywa (2011), the strength of the National Treasury in inter-departmental decision-making is extremely powerful. The practice is that "organs of the state follow National Treasury prescripts" with the consequence that the B-BBEE Act has largely been unused in state procurement (Mesatywa, 2011: 9).

Current support directions are therefore linked to implementation of the Preferential Procurement Act, which gives "preference" in tenders to black suppliers. Other initiatives surround the establishment of a National Procurement Portal. The intention of this initiative is to address poor access to markets by creating a platform that will host all procurement/ tender opportunities of government departments. In addition, it would do the following. First, it would improve information accessibility about opportunities to suppliers and information to buyers so as to increase the participation of small enterprises in public sector tendering and in requests for quotes. Second, it would streamline procurement processes in order to reduce the administrative burden for SMMEs. Third, it would support collaboration between the public and private sectors on information about opportunities. Fourth, it would enhance adherence to timings/deadlines on contract advertisement, award, delivery and payment cycles. Last, it would strengthen information access and transparency of government procurement processes (Breytenbach, 2011).

Overall, however, it has been pointed out that, although the national government in South Africa is the champion of B-BBEE policy as well as SMME development and the largest procurer of goods and services in the country, examination of its own procurement spending and procedures suggests that it is not "walking the talk" because it is not supporting its own policies in its practices (Herrington \& Overmeyer, 2006: 25). Critically, it is revealed that government spending has not only been insufficient for preferential procurement but also (and especially so) with regard to its contribution to (black) small enterprise development. Further criticism can be directed at the national government for raising expectations that market access for SMMEs would be improved through the government's own initiatives but then failing to implement promised policies and procedures that had already been announced. One recent detailed report on public procurement in South Africa contains several critical policy findings relating to SMMEs (Kaiser Associates, 2010). First, it is concluded that as a consequence of definitional problems with SMMEs and weak data-gathering processes "it is not possible to develop a full picture of public procurement from SMMEs in South Africa" (Kaiser Associates, 2010: i). Second, few organs of government actually set targets for procurement from SMMEs and, even in cases where targets are set, often they are only for a subset of procurement opportunities. Third, although preferential procurement by state departments supports SMMEs, including through information sharing and early payment cycles, there are missed opportunities in which centralised (as opposed to decentralised) procurement systems exist because these preclude the supply of large contracts to SMMEs. Fourth, criticism is levelled at the fact that there seems to be no mechanism that links together and integrates different types of government support for SMMEs with market access to procurement opportunities. Although it is evident that SMMEs attach importance to government support programmes targeted at their development, considerable gaps in support structures exist and there is a mismatch between existing programmes and the actual needs of SMMEs (Kaiser Associates, 2010: v). Fifth, data on the precise value and number of contracts obtained by SMMEs is unavailable because existing government management information systems lack cohesion and are uncoordinated (Kaiser Associates, 2010). For example, there is "no common system for data collection and management as well as lack of functionality in data capturing systems due to various levels of technical capacity" (Kaiser Associates, 2010: 85). Sixth, opportunities are identified for the expansion of public procurement from SMMEs particularly in those goods and services that can be procured in small quantities (food and beverages), products that do not demand high skills, technology or capital input (gardening, maintenance repairs), products that do not constitute a high risk to buyers (office supplies, stationary) and rural/highly localised services in which products are currently not locally supplied because of scale considerations (Kaiser Associates, 2010). Seventh, concern is expressed that the current direction of "preferential procurement legislation is shifting toward BBBEE enterprises, and away from SMMEs" (Kaiser Associates, 2010: 9).

As a whole, this shift is reflected in the emphasis given to B-BBEE points in the new procurement regulations that were gazetted in the June 2011 regulations that seek to align the B-BBEE policy with the Public Procurement Policy Framework Act (Mesatywa, 2011). From the perspective of the $\mathrm{Na}$ tional Treasury, the outcome of these regulations is that public 
procurement in South Africa must be directed by preferences to be given to SMMEs rather than through use of set-asides. The danger remains, however, that the benefits of this preference may well be captured by larger black-owned enterprises rather than the actual target group of SMMEs.

\section{Conclusion}

Building dynamic urban economies is a challenge faced by governments and planners across Africa (Turok, 2010, 2012). One facet of creating more productive urban economies is improving the status and growth potential of small-scale enterprises. Improving the position of black-owned SMMEs and getting them into the mainstream economy has been one of the most difficult policy challenges of the post-apartheid period in South Africa. More specifically, it represents a critical issue for urban economic development and particularly for creating inclusive cities (see Grant, 2010; Rogerson, 2010; Turok, 2012). Disappointments surrounded the first decade of government policy initiatives to improve the position of black-owned SMMEs, most of which remain largely marginal to the mainstream economy. New policy directions have consolidated since 2006 with regard to building opportunities for SMMEs within private sector procurement as well as strengthening their position under public procurement. Current policy directions, however, are biased towards assisting the improvement of urban SMMEs in terms of access to these market opportunities. Spatial disadvantage therefore remains a problem. The challenge of sectoral disadvantage is being addressed through information support and assistance in programmes linked to priority growth sectors with potential, and can be addressed further through expanded access to market opportunities from both private and public sector procurement. Competitive disadvantage is of greatest concern and is being addressed only through supplier diversity initiatives.

Arguably, the South African government has consistently acknowledged the critical importance of improving the capacity of (black-owned) SMMEs to participate in the mainstream economy. To achieve success, however, a set of integrated interventions are required, encompassing financing, regulatory change and the emerging initiatives to expand market access (Osiba Research, 2011). This analysis shows that the national government recognises its own capacity limitations to implement SMME improvement and build competitive black-owned SMMEs. This has prompted government endorsement and the beginnings of a promising partnership with the private sector to promote supplier diversity based on the business case for expanding links rather than B-BBEE scorecards. In addition, the national government is struggling to practice what it preaches and apply its own procurement capac- ity to assist SMMEs, especially the community of black-owned SMMEs.

Christian M. Rogerson

University of Johannesburg, School of Tourism and Hospitality, South Africa

E-mail: crogerson@uj.ac.za

\section{Acknowledgements}

Thanks to the journal editors and referees for strengthening the urban focus of this contribution. Research funding is acknowledged from the National Research Foundation, Pretoria. A shorter version of this article was presented at the Association of American Geographers Annual Meeting, Los Angeles, April 2013.

\section{References}

Adobor, H. \& McMullen, R. (2007) Supplier diversity and supply chain management: A strategic approach. Business Horizons, 50(3), pp. 219229. DOI: 10.1016/j.bushor.2006.10.003

Altman, M. (2010) Procurement will boost the small business sector. Municipal Focus, 2(3), pp. 40-43.

Bates, T. (2001) Minority business access to mainstream markets. Journal of Urban Affairs, 23(1), pp. 41-56. DOI: 10.1111/0735-2166.00074

Bolton, P. (2006) Government procurement as a policy tool in South Africa. Journal of Public Procurement, 6(3), pp. 193-217.

Bolton, P. (2008) Protecting the environment through public procurement: The case of South Africa. Natural Resources Forum, 32(1), pp. 1-8. DOI: 10.1111/j.1477-8947.2008.00171.x

Boraine, A., Crankshaw, O., Engelbrecht, C., Gotz, G., Mbanga, S., Narsoo, M. \& Parnell, S. (2006) The state of South African cities a decade after democracy. Urban Studies, 43(2), pp. 259-284. DOI: $10.1080 / 00420980500416990$

Botha, M. \& Van Vuuren, J. (2006) Identifying the criteria that large corporations (JSE-listed) make use of when dealing with Broad Based Black Economic Empowered (BBBEE) small and medium-sized enterprises. Unpublished consulting report. Johannesburg.

Breytenbach, T. (2011) Integrated Small Enterprises Supplier Development Programme. Pretoria, Small Enterprise Development Agency.

Bryceson, D. \& Potts, D. (eds.) (2006) African urban economies: Viability, vitality or vitiation? Basingstoke, Palgrave.

Department of Economic Development (2010) The New Growth Path framework. Pretoria.

Department of Trade and Industry (2006) Integrated Small-Enterprise Development Strategy: Unlocking the potential of South African entrepreneurs. Pretoria.

Department of Trade and Industry (2011) Medium-Term Strategic Plan, Pretoria.

Freund, B. (2010) Is there such a thing as a post-apartheid city? Urban Forum, 21(3), pp. 283-298. DOI: 10.1007/s12132-010-9087-4

Grant, R. (2010) Working it out: Labour geographies of the poor in Soweto, South Africa. Development Southern Africa, 27(4), pp. 595-612. DOI: 10.1080/0376835X.2010.508595 
Herrington, M. D. \& Overmeyer, T. (2006) Study on the procurement relationship between large corporations and mainly black owned or empowered SMEs. Research report. Johannesburg, University of Cape Town, Graduate School of Business.

House-Soremekun, B. (2007) The impact of minority set-aside programs on black business success in Cleveland, Ohio: Implications for public policy. Western New England Law Review 30(19), pp. 19-37.

Ismael, A. \& Haselau, K. (2010) SASDC operations. Paper presented at the SASDC Steering Committee Workshop, 26 November, Sandton, South Africa. Typescript.

Jenkins, B. (2007) Expanding economic opportunity: The role of large firms. Washington DC, International Finance Corporation, International Business Leaders Forum and the CSR Initiative of the Harvard Kennedy School.

Jenkins, B. \& Ishikawa, E. (2009) Business linkages: Enabling access to markets at the base of the pyramid. Washington DC, International Finance Corporation, International Business Leaders Forum and the CSR Initiative of the Harvard Kennedy School.

Joseph, G. (2010) SASDC strategy: Intent and leadership. Paper presented at the SASDC Steering Committee Workshop, 26 November, Sandton, South Africa. Typescript.

Juggernauth, S., Rampersad, R. \& Reddy, K. (2011) Corporate responsibility for socio-economic transformation: A focus on broad-based black economic empowerment and its implementation in South Africa. African Journal of Business Management, 5(20), pp. 8224-8234.

Kaiser Associates (2010) Public sector procurement from small, medium and micro enterprises (SMMEs). Cape Town.

Kessides, C. (2007) The urban transition in sub-Saharan Africa: Challenges and opportunities. Environment and Planning C, 25(4) pp. 466-485. DOI: $10.1068 / c 3 p$

Ligthelm, A. (2012) The viability of informal micro businesses in South Africa: A longitudinal analysis (2007 to 2011). African Journal of Business Management, 6(46), pp. 11416-11425.

Mahmood, S. A. I. (2010) Public procurement and corruption in Bangladesh: Confronting the challenges and opportunities. Journal of Public Administration and Policy Research, 2(6), pp. 103-111.

Meagher, K. (2010) The tangled web of associational life: Urban governance and the politics of popular livelihoods in Nigeria. Urban Forum, 21(3), pp. 299-313.

Mesatywa, N. (2011) Levering public procurement. Paper presented at the Annual Small Business Summit, 12 October, Bloemfontein, South Africa. Typescript.

National Business Initiative (2006a) Report on commercial linkages between large enterprises and small enterprises in South Africa. Unpublished research report. Johannesburg.

National Business Initiative (2006b) Support by large enterprises of small enterprise suppliers in the value chain: A summary of findings and key proposals. Unpublished research report. Johannesburg.

Nel, E. \& Rogerson, C. M. (eds.) (2005). Local economic development in the developing world. New Brunswick, NJ, Transaction Publishers.

Orser, B. (2009) Procurement strategies to support women-owned enterprises. Ottawa, Canada Works Limited.

Osiba Research (2011) Rethinking small business support in South Africa. Unpublished research report. Pretoria.

Presidency, The (2011) National development plan: Vision for 2030. Pretoria, National Planning Commission.

Ram, M. \& Smallbone, D. (2003a) Supplier diversity initiatives and diversification of ethnic minority businesses in the UK. Policy Studies, 24(4), pp. 187-204. DOI: 10.1080/0144287042000216117

Ram, M. \& Smallbone, D. (2003b) Policies to support ethnic minority enterprise: The English experience. Entrepreneurship and Regional Development, 15(2), pp. 151-166. DOI: 10.1080/0898562032000075177

Rogerson, C. M. (1997) Globalization or informalization? African urban economies in the 1990s. In: Rakodi, C. (ed.) Managing urban growth in Africa, pp. 337-370. Tokyo, United Nations University Press.

Rogerson, C. M. (2004a) Ten years of changing development planning in a democratic South Africa. International Development Planning Review, 26(4), pp. 355-358. DOI: 10.3828/idpr.26.4.1

Rogerson, C. M. (2004b) The impact of the South African government's SMME programmes: a ten year review, Development Southern Africa, 21(5), pp. 765-784. DOI: 10.1080/0376835042000325697

Rogerson, C. M. (2004c) Urban tourism and small tourism enterprise development in Johannesburg: The case of township tourism. GeoJournal, 60(3), pp. 249-257. DOI: 10.1023/B:GEJO.0000034732.58327.b6

Rogerson, C. M. (2006) The market development approach to SMME development: Implications for local government in South Africa, Urban Forum, 17(1), pp. 54-78.

Rogerson, C. M. (2008) Tracking SMME development in South Africa: Issues of finance, training and the regulatory environment. Urban Forum, 19(1), pp. 61-81.

Rogerson, C. M. (2010) Local economic development in South Africa: Key strategic challenges. Development Southern Africa, 27(4), pp. 481-495. DOI: 10.1080/0376835X.2010.508580

Rogerson, C. M. (2011) Tracking local economic development policy and practice in South Africa, 1994-2009. Urban Forum, 22(2), pp. 149-168.

Rogerson, C. M. (2012) Supplier diversity: A new phenomenon in private sector procurement in South Africa. Urban Forum, 23(3), pp. 279-297.

Rogerson, C. M. \& Rogerson, J. M. (2010) Local economic development in Africa: Global context and research directions, Development Southern Africa, 27(4), pp. 465-480. DOI: 10.1080/0376835X.2010.508577

Rogerson, C. M. \& Rogerson, J. M. (2012) Business development and local economic development in South Africa: Addressing the disconnect. Acta Academica, 44(2), pp. 41-69.

Schenck, R. \& Blaauw, P. F. (2011) The work and lives of street waste pickers in Pretoria - A case study of recycling in South Africa's urban informal economy. Urban Forum, 22(4), pp. 411-430.

Skae, O. (2006) Preferential procurement - A needs assessment of large scale enterprises and what constitutes best practice: A South African perspective. Unpublished research report. Johannesburg.

Sonfield, M. (2010) Ethnic minority businesses and targeted assistance programs in the U.S. and the UK: A comparison and implications. Small Business Institute National Proceedings, 34(Winter), pp. 11-17.

South African Supplier Diversity Council (2011) Strategic Plan 20112016. Johannesburg.

Thai, K. V. (2001) Public procurement re-examined. Journal of Public Procurement, 1(1), pp. 9-50.

Thornton, A. \& Rogerson, C. M. (2013) African cities and the millennium development goals: A case for applied geography. Applied Geography, 36(1), pp. 1-2. DOI: 10.1016/j.apgeog.2012.09.004

Timm, S. (2011) How South Africa can boost support to small businesses: Lessons from Brazil and India. Pretoria, Trade and Industrial Policy Secretariat.

Toomey, D. C. (1998) South African small business growth through interfirm linkages. Unpublished doctoral thesis. Grahamstown, Rhodes University, Faculty of Humanities. 
Turok. I. (2010) The prospects for urban African economies. Urban Research and Practice, 3(1), pp. 12-24.

Turok, I. (2012) Unleashing the economic potential of African cities. Paper presented at the UN Habitat Workshop, 23-24 February, Cape Town, South Africa. Typescript.

Turok, I. \& Parnell, S. (2009) Reshaping cities, rebuilding nations: The role of national urban policies. Urban Forum, 20(2), pp. 157-174.

United Nations Conference on Trade and Development (2006) Business Linkages Programme Guidelines. New York and Geneva.

Urban, B. (2006) Entrepreneurship in the rainbow nation. Journal of Developmental Entrepreneurship, 11(3), pp. 171-186.

DOI: $10.1142 / S 1084946706000386$ 